\title{
Comparison of Working Conditions and Prevalence of Musculoskeletal Symptoms among Dairy Farmers in Southern Sweden over a 25-Year Period
}

\section{OPEN ACCESS}

Edited by:

Martina Carola Jakob,

Leibniz Institute for Agricultural Engineering Potsdam-Bornim,

Germany

Reviewed by: Yuke Tien Fong,

Singapore General Hospital,

Singapore

Siti Munira Yasin, Universiti Teknologi MARA, Malaysia

${ }^{*}$ Correspondence: Stefan Pinzke stefan.pinzke@s/u.se

Specialty section: This article was submitted to Occupational Health and Safety, a section of the journal Frontiers in Public Health

Received: 29 February 2016 Accepted: 02 May 2016

Published: 19 May 2016

Citation:

Pinzke S (2016) Comparison of Working Conditions and Prevalence of Musculoskeletal Symptoms among Dairy Farmers in Southern Sweden over a 25-Year Period.

Front. Public Health 4:98. doi: 10.3389/fpubh.2016.00098

\section{Stefan Pinzke*}

Department of Work Science, Business Economics and Environmental Psychology, Swedish University of Agricultural Sciences, Alnarp, Sweden

Working conditions and the prevalence of perceived musculoskeletal symptoms (MSSs) among dairy farmers in 2013 were monitored by repeating a mail survey of dairy workers in Scania, southern Sweden, using the same method for collecting data on MSSs and working conditions employed in previous surveys conducted in 1988 and 2002. All dairy enterprises in Scania (total 419) were sent two copies of a questionnaire. One or more responses were received from 232 enterprises (55.4\%), of which those from 247 dairy farmers (75\% men and 25\% women) in 199 enterprises are included in this study. The farmers had increased their weekly working hours in 2013 compared with 2002 (males $\bar{x}=43.9,40.7$; females $\bar{x}=37.9,33.9$ ). Each male milked on average 30 cows in 1988, 44 cows in 2002, and 86 cows in 2013. The corresponding numbers milked by female farmers were 29, 60, and 102, respectively. In 1988, almost all farmers used tethered systems, while in $2013,54.4 \%$ of male and $66.1 \%$ of female farmers instead worked with loose-housing systems. Of the farmers who used loose-housing systems, 50.7\% had a robotic milking system. In $2013,79.0 \%$ of male and $88.5 \%$ of female farmers reported MSSs on some occasion, especially in the lower back, shoulders, and knees for men, and in the shoulders, lower back, and wrists/hands for women. However, there was no statistical change compared with the frequency of MSSs in 2002. In 2013, there was a tendency for younger dairy farmers ( $\leq 35$ years) to report MSSs, especially in the shoulders, elbows, lower back, and feet, more frequently than younger farmers in 2002. The males who worked with robot milking systems in 2013 indicated less discomfort in the shoulders than men who worked with other systems. The corresponding females indicated fewer problems in the lower back in 2013. Various aspects of milking system design and technology have been improved to reduce the workload and prevent MSSs in dairy farmers. Nevertheless, more improvements are needed to make the milking process more attractive and reduce health problems, especially in younger farmers currently working with milking and in new recruits.

Keywords: musculoskeletal symptoms, survey, physical exposure, ergonomics, agriculture, dairy farming 


\section{INTRODUCTION}

\section{Dairy Farming and Musculoskeletal Symptoms}

Dairy farming in the developed countries worldwide has undergone intensive rationalization over recent decades, leading to fewer operations but larger herd size (1-4). Along with this rationalization, there has been a transition from manual milking in tethered (stanchion) systems to machine milking in loose-housing systems. In tethered systems, which are often used in small-scale dairy farms with smaller herd size $(5,6)$, the cows are tethered in separate stalls while they are milked. The dairy farmer brings the milking equipment to the cows and stands in between them, kneeling or squatting to perform the work (5, 7). In small-scale dairy farms, it is often the farmer himself who also has to perform other strenuous tasks in addition to milking, such as manual scraping of manure, handling of feed, strewing of litter, and cleaning (8). In loose-housing systems that are more

TABLE 1 | Number of farms and total number of farmers, divided into males and females, included in the surveys in 2013, 2002, and 1988, and response rates to the questionnaire.

\begin{tabular}{cccccc}
\hline Year & No. of farms & $\begin{array}{c}\text { No. of } \\
\text { farmers }\end{array}$ & Male & Female & $\begin{array}{c}\text { Response } \\
\text { rate (\%) }\end{array}$ \\
\hline 2013 & 199 & 247 & 186 & 61 & 55 \\
2002 & 504 & 686 & 494 & 188 & 67 \\
1988 & 1058 & 1465 & 1077 & 388 & 81 \\
\hline
\end{tabular}

popular among larger dairy farms $(7,9)$, the milking takes place in a dedicated facility where the milking equipment is stationary. The farm worker performs the milking tasks standing in a more upright posture, either in a milking pit below the cows or at a rotary where the cows pass by on an elevated platform $(5,7,9)$. In large-scale dairy farms, the workers are often assigned specific farm operations, such as milking, doing the same highly repetitive and specialized tasks for an entire work shift (8-11).

Automatic milking systems where the milking is performed by robots in milking stations, without depending on human labor, have been used for 20 years in Europe, but have only recently become more popular in North America, in smaller herds with one station and in larger herds with several robotic stations $(7,12,13)$.

It is well documented that the milking work in tethered systems is physically demanding, associated with lifting heavy objects, moving and carrying equipment, and awkward working postures, all which are risk factors for development of musculoskeletal symptoms (MSSs), especially in the shoulders, lower back, and knees $(5,10,14,15)$. The repetitive and monotonous milking work in loose-housing systems is considered to pose risk factors for developing MSSs in the upper extremities, especially in the shoulders and wrists/hands (8-10, 15-20).

\section{Swedish Conditions}

In 1990 , there were 25,921 farm businesses with dairy cows in Sweden. However, by 2000 , this number had fallen to 12,676 , in 2010 to 5619 , and in 2013 down to 4668 businesses. The average

TABLE 2 | Description and comparison of dairy farmers and their work situation in 1988, 2002, and 2013.

\begin{tabular}{|c|c|c|c|c|c|c|c|c|c|c|c|c|c|}
\hline & & \multicolumn{4}{|c|}{2013} & \multicolumn{4}{|c|}{2002} & \multicolumn{4}{|c|}{1988} \\
\hline & & $n$ & Mean & SD & Range & $n$ & Mean $^{\mathrm{e} / \mathrm{f}}$ & SD & Range & $n$ & Mean $^{\mathrm{e} / \mathrm{g}}$ & SD & Range \\
\hline \multirow[t]{2}{*}{ Age (year) } & Males & 184 & $53.5^{d}$ & 10.98 & 21-83 & 493 & $49.4^{\mathrm{b} / \mathrm{d}}$ & 11.00 & 20-79 & 1077 & $47.7^{\mathrm{c} / \mathrm{c}}$ & 11.89 & 15-81 \\
\hline & Females & 61 & 46.3 & 13.60 & 19-71 & 188 & 47.3 & 10.60 & 20-68 & 388 & 45.8 & 10.89 & 19-75 \\
\hline \multirow{2}{*}{$\begin{array}{l}\text { No. of years as a } \\
\text { dairy farmer }\end{array}$} & Males & 185 & $32.6^{d}$ & 12.24 & $3-70$ & 494 & $26.6^{\mathrm{d} / \mathrm{d}}$ & 12.21 & $1-55$ & 1074 & $26.1^{d}$ & 14.16 & $1-65$ \\
\hline & Females & 60 & 21.8 & 13.36 & $1-50$ & 186 & 20.6 & 10.83 & $2-57$ & 386 & 21.3 & 13.42 & $1-50$ \\
\hline \multirow{2}{*}{$\begin{array}{l}\text { Hours worked per } \\
\text { week }\end{array}$} & Males & 182 & $43.9^{b}$ & 16.89 & $7-119$ & 490 & $40.7^{\mathrm{d} / \mathrm{b}}$ & 14.58 & $2-112$ & 1066 & $36.3^{d / d}$ & 12.39 & $4-85$ \\
\hline & Females & 60 & 37.9 & 15.75 & $12-100$ & 187 & $33.9^{/ a}$ & 13.10 & $4-70$ & 379 & $27.7^{/ d}$ & 10.86 & $3-88$ \\
\hline \multirow[t]{2}{*}{ Body weight (kg) } & Males & 184 & $84.2^{\mathrm{d}}$ & 11.62 & $58-116$ & 492 & $82.0^{\mathrm{d} / \mathrm{b}}$ & 10.70 & $58-135$ & 1067 & $79.4^{d / d}$ & 9.91 & $42-122$ \\
\hline & Females & 60 & 70.2 & 12.11 & $50-100$ & 178 & 69.5 & 10.75 & $45-100$ & 377 & $65.6^{/ d}$ & 8.77 & $50-100$ \\
\hline \multirow[t]{2}{*}{ Body height (cm) } & Males & 185 & $180.9^{d}$ & 7.10 & $157-200$ & 490 & $179.6^{\mathrm{d} / \mathrm{b}}$ & 6.79 & $152-200$ & 1069 & $177.7^{\mathrm{d} / \mathrm{d}}$ & 6.46 & 150-205 \\
\hline & Females & 60 & 167.3 & 6.15 & $150-181$ & 183 & 166.9 & 5.72 & 150-185 & 382 & $165.4^{/ \mathrm{c}}$ & 5.81 & $150-182$ \\
\hline \multirow{2}{*}{$\begin{array}{l}\text { Body mass index } \\
\left(\mathrm{kg} / \mathrm{m}^{2}\right)\end{array}$} & Males & 183 & 25.7 & 3.16 & $18.6-36.8$ & 488 & 25.4 & 2.95 & $18.2-41.7$ & 1065 & $25.1^{1 / a}$ & 2.76 & $17.0-36.8$ \\
\hline & Females & 60 & 25.1 & 3.95 & $17.9-35.9$ & 177 & 25.0 & 3.77 & $17.6-39.1$ & 375 & $24.0^{\prime c}$ & 2.97 & $17.9-34.6$ \\
\hline \multirow{2}{*}{$\begin{array}{l}\text { No. of cows } \\
\text { milked }\end{array}$} & Males & 185 & 85.8 & 72.72 & $8-650$ & 492 & $55.7^{/ d}$ & 44.16 & 3-320 & 1077 & $30.1^{/ d}$ & 24.74 & $2-300$ \\
\hline & Females & 60 & 102.3 & 82.39 & $8-420$ & 188 & $59.2^{/ d}$ & 47.23 & $12-320$ & 386 & $29.3^{/ d}$ & 17.98 & $1-160$ \\
\hline
\end{tabular}

Descriptive values ( $n$, mean, $S D$, and range), divided by sex.

${ }^{a} p<0.10$.

${ }^{b} p<0.05$.

${ }^{c} p<0.01$.

${ }^{d} p<0.001$.

${ }^{e}$ Differences between sexes (independent samples t-test).

${ }^{t}$ Differences between dairy farmers in 2013 and 2002 (independent samples t-test).

${ }^{9}$ Differences between dairy farmers in 2002 and 1988 (independent samples t-test).

Significant increases in values between the 2002 and 2013 surveys are marked in red.

The superscript "/" separates the significant levels ( $a, b, c, d)$ of the tests with respect to sex (test e) and survey years (tests f, g). 
herd size increased over the period, from 22 cows in 1990 to 34 cows in 2000, 62 cows in 2010, and 74 cows in 2013 (21-24).

Most large dairy herds (both in numbers and as a percentage) are located in the province of Scania in southern Sweden. The number of herds in Scania with more than 75 cows increased from 76 in 1990 to 130 in 2000 and to 179 in both 2010 and 2013, while the total number of dairy farms in Scania decreased in those years from 2718 to 1198,510 , and 419, respectively (21-24).

Earlier studies in 1988 and 2002 on dairy farmers in Scania showed that the rationalization described above, along with mechanization and automation of the work, had resulted in a change in pattern concerning working conditions and health for individual farmers $(14,15)$. In $2002,83 \%$ of male and $90 \%$ of female dairy farmers surveyed in Sweden reported some form of perceived MSSs during the previous 12 months. This was an increase compared with the survey in 1988, especially as regards problems in the neck, shoulders, and wrists/hands. By
2002, milkers had increased, on average, their working hours per week, the number of cows milked, and the use of more milking units (15).

In 1988, almost all dairy farmers were working in traditional tethered systems, whereas in 2002, about $25 \%$ were working in loose-housing systems (15).

Most dairy farmers in both the 1988 and 2002 survey, irrespective of age or sex, thought that silage handling and milking were their most strenuous tasks. However, the milkers derived their greatest pleasure from the actual milking task, as well from their work with caring for the animals (15).

Overall, the earlier studies $(14,15)$ showed that individual factors, such as sex, age, and weight, as well as those factors related to work organization and the physical workplace, such as number of hours worked per week, number of cows milked, the milking system used, and the age of the farm building, had significant impacts on the prevalence of MSSs.

TABLE 3 | Description and comparison of the dairy farmers and their work situation in 1988, 2002 , and 2013.

\begin{tabular}{|c|c|c|c|c|c|c|c|c|}
\hline & & & \multicolumn{2}{|c|}{2013} & \multicolumn{2}{|c|}{2002} & \multicolumn{2}{|c|}{1988} \\
\hline & & & $n$ & $\%$ e & $n$ & $\%$ e/f & $n$ & $\%{ }^{e / g}$ \\
\hline \multirow[t]{4}{*}{ Employment form } & Males & Employed & 9 & $5.0^{d}$ & 29 & $6.1^{d}$ & 45 & 4.2 \\
\hline & & Self-employed & 171 & 95.0 & 446 & 93.9 & 1032 & 95.8 \\
\hline & Females & Employed & 12 & 19.7 & 28 & 15.5 & 10 & $2.6^{\prime d}$ \\
\hline & & Self-employed & 49 & 80.3 & 153 & 84.5 & 378 & 97.5 \\
\hline \multirow[t]{6}{*}{ Handedness } & Males & Right & 175 & 94.1 & 445 & $89.9^{\prime a}$ & 994 & 92.3 \\
\hline & & Left & 6 & 3.2 & 38 & 7.7 & 68 & 6.3 \\
\hline & & Ambidextrous & 5 & 2.7 & 12 & 2.4 & 15 & 1.4 \\
\hline & Females & Right & 57 & 93.4 & 176 & 92.6 & 359 & 92.5 \\
\hline & & Left & 4 & 6.6 & 11 & 5.8 & 21 & 5.4 \\
\hline & & Ambidextrous & 0 & 0 & 3 & 1.6 & 8 & 2.1 \\
\hline \multirow[t]{6}{*}{ Housing system } & Males & Tethered & 83 & 45.6 & 365 & $74.0^{\prime d}$ & 1032 & $95.8^{\mathrm{b} / \mathrm{d}}$ \\
\hline & & Loose-housing & 87 & 47.8 & 115 & 23.3 & 24 & 2.2 \\
\hline & & Both & 12 & 6.6 & 13 & 2.6 & 21 & 1.9 \\
\hline & Females & Tethered & 20 & 33.9 & 135 & $71.4^{/ d}$ & 381 & $98.2^{/ d}$ \\
\hline & & Loose-housing & 35 & 59.3 & 46 & 24.3 & 3 & 0.8 \\
\hline & & Both & 4 & 6.8 & 8 & 4.2 & 4 & 1.0 \\
\hline \multirow[t]{12}{*}{ Building date } & Males & -1969 & 15 & 8.2 & 31 & $6.4^{/ d}$ & 332 & $31.2^{/ d}$ \\
\hline & & 1970-1979 & 23 & 12.6 & 117 & 24.0 & 491 & 46.2 \\
\hline & & 1980-1989 & 28 & 15.4 & 110 & 22.5 & 240 & 22.6 \\
\hline & & 1990-1999 & 42 & 23.1 & 197 & 40.4 & & \\
\hline & & 2000-2009 & 53 & 29.1 & 33 & 6.8 & & \\
\hline & & 2010- & 21 & 11.5 & & & & \\
\hline & Females & -1969 & 4 & 6.6 & 11 & $6.0^{\prime d d}$ & 104 & $27.1^{1 / d}$ \\
\hline & & 1970-1979 & 9 & 14.8 & 44 & 23.9 & 190 & 49.5 \\
\hline & & 1980-1989 & 6 & 9.8 & 42 & 22.8 & 90 & 23.4 \\
\hline & & 1990-1999 & 10 & 16.4 & 72 & 39.1 & & \\
\hline & & 2000-2009 & 19 & 31.1 & 15 & 8.2 & & \\
\hline & & 2010- & 13 & 21.3 & & & & \\
\hline
\end{tabular}

Frequency values ( $n$ and \%), divided by sex.

${ }^{a} p<0.10$.

${ }^{b} p<0.05$.

${ }^{c} p<0.01$.

${ }^{d} p<0.001$.

eDifferences between sexes (Mann-Whitney $U$ test).

${ }^{\mathrm{f} D i f f e r e n c e s ~ b e t w e e n ~ d a i r y ~ f a r m e r s ~ i n ~} 2013$ and 2002 (Mann-Whitney $U$ test).

${ }^{9}$ Differences between dairy farmers in 2002 and 1988 (Mann-Whitney U test).

Significant increases in values between the 2002 and 2013 surveys are marked in red and significant decreases in green.

The superscript "/" separates the significant levels ( $a, b, c, d)$ of the tests with respect to sex (test e) and survey years (tests f, g). 
TABLE 4 | Frequency of perceived symptoms [number (n) and \%] in the musculoskeletal system at some time during the past 12 months among dairy farmers, divided by sex, in 2013, 2002, and 1988.

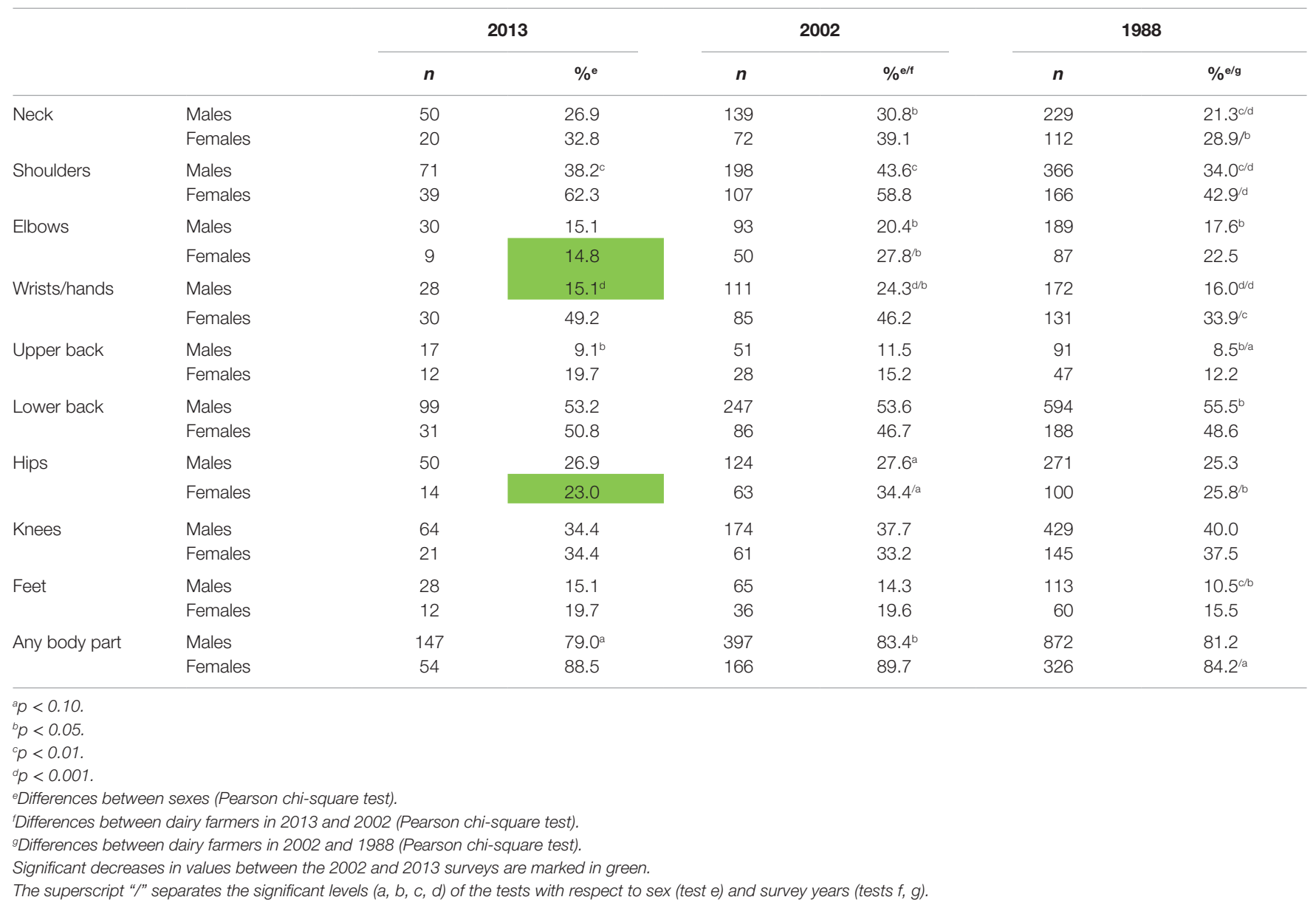

The primary aim of the present study was to monitor the current prevalence of MSSs, individual conditions, and the work situation among Scanian dairy farmers by repeating the previous surveys from 1988 and 2002. The objective was to clarify trends on the prevalence of MSSs and the effects on farmers of an additional 10 years of exposure to their work environment, especially to the risk factors found in the previous surveys. The secondary aim was to describe some good practices and technical aids and solutions that can be adopted in different milking systems managed by dairy farmers in order to reduce the workload and prevent MSSs.

\section{MATERIALS AND METHODS}

The same questionnaire as was used in 1988 and 2003 was employed in the present survey. It comprised questions on perceived MSSs based on the standardized Nordic Musculoskeletal Questionnaires (25), as well as questions about personal characteristics and working conditions. These included items such as the number of cows milked per day, the milking system used, technical aids, occurrence of injuries and health problems beside MSSs, degree of mechanization of the work, which work task the respondents considered to be the most strenuous and which gave the most job satisfaction $(26,27)$. The questions used regarding MSSs were whether the respondents at some time had (yes/no) perceived ache, pain, or discomfort in the neck, shoulder, elbow, wrist/hand, upper back, lower back, hip, knee, and/or feet during the previous 12 months.

The names and addresses of all dairy farm businesses in Scania (in total 419) listed in the national Farm Register (LBR, 2013) were obtained from the Swedish Board of Agriculture. Each business received two questionnaires by mail in April 2014, enabling two people involved daily, or more regularly, in the milking work (i.e., milkers), e.g., husband and wife, owner and employee, or two employees, to respond. Two reminders were sent out in May 2014 to obtain an acceptable response rate. The first reminder consisted of only a reminder card with a request to complete the questionnaire, whereas with the second reminder, two new questionnaires were sent to those farmers who did not answer the first mailing. In this second mailing, there was also an opportunity to indicate the reason for not participating in the survey.

Of the 418 dairy businesses to which the survey was sent (one business did not receive a mailing because it had an address abroad), 232 businesses responded (55.4\%) and 33 did not return a completed questionnaire. Of the latter, 14 had ceased production, were not milking, had no cows, or were deceased; 6 cited lack of time; 5 cited other reasons; and 8 did not state any reason why they did not participate in the study. This means that 247 
TABLE 5 | Description and comparison of dairy farmers with and without reported musculoskeletal symptoms in 2013.

\begin{tabular}{|c|c|c|c|c|c|c|c|c|c|}
\hline & & \multicolumn{4}{|c|}{ Symptoms 2013} & \multicolumn{4}{|c|}{ No symptoms 2013} \\
\hline & & $n$ & Mean & SD & Range & $n$ & Mean $^{\mathrm{e} / \mathrm{f}}$ & SD & Range \\
\hline \multirow[t]{3}{*}{ Age (year) } & Males & 147 & $53.5^{d}$ & 10.96 & $21-83$ & 37 & 53.5 & 11.17 & $26-72$ \\
\hline & Females & 54 & 45.9 & 13.57 & 19-70 & 7 & 49.3 & 14.56 & 29-71 \\
\hline & Total & 201 & 51.5 & 12.17 & 19-83 & 44 & 52.8 & 11.68 & 26-72 \\
\hline \multirow{3}{*}{$\begin{array}{l}\text { No. of years as a dairy } \\
\text { farmer }\end{array}$} & Males & 146 & $32.6^{d}$ & 12.15 & $4-70$ & 39 & $32.9^{b}$ & 12.73 & $3-60$ \\
\hline & Females & 53 & 21.8 & 13.56 & $1-50$ & 7 & 21.9 & 12.66 & $2-40$ \\
\hline & Total & 199 & 29.7 & 13.38 & $1-70$ & 46 & 31.2 & 13.20 & $2-60$ \\
\hline \multirow[t]{3}{*}{ Hours worked per week } & Males & 143 & $42.6^{a}$ & 16.11 & $7-119$ & 39 & $48.7^{/ b}$ & 18.94 & $20-105$ \\
\hline & Females & 53 & 37.6 & 15.32 & $12-100$ & 7 & 40.0 & 20.0 & $20-70$ \\
\hline & Total & 196 & 41.2 & 16.01 & $7-119$ & 46 & $47.4^{/ b}$ & 19.13 & $20-105$ \\
\hline \multirow[t]{3}{*}{ Body weight (kg) } & Males & 145 & $84.7^{\mathrm{d}}$ & 11.53 & $58-116$ & 39 & $82.3^{c}$ & 11.94 & $59-110$ \\
\hline & Females & 53 & 70.4 & 12.25 & $50-100$ & 7 & 68.7 & 11.76 & $55-91$ \\
\hline & Total & 198 & 80.9 & 13.31 & $50-116$ & 46 & 80.2 & 12.77 & $55-110$ \\
\hline \multirow[t]{3}{*}{ Body height (cm) } & Males & 147 & $181.0^{d}$ & 7.10 & $157-200$ & 38 & $180.4^{d}$ & 7.14 & $170-193$ \\
\hline & Females & 53 & 167.5 & 6.30 & $150-181$ & 7 & 165.9 & 5.05 & $160-172$ \\
\hline & Total & 200 & 177.4 & 9.13 & 150-200 & 45 & 178.2 & 8.65 & $160-193$ \\
\hline \multirow[t]{3}{*}{ Body mass index $\left(\mathrm{kg} / \mathrm{m}^{2}\right)$} & Males & 145 & 25.9 & 3.10 & $19.9-36.8$ & 38 & 25.2 & 3.38 & $18.6-35.3$ \\
\hline & Females & 53 & 25.1 & 4.04 & $17.9-35.9$ & 7 & 25.0 & 3.77 & $20.2-30.8$ \\
\hline & Total & 198 & 25.7 & 3.39 & $17.9-36.8$ & 45 & 25.2 & 3.35 & $18.6-35.3$ \\
\hline \multirow[t]{3}{*}{ No. of cows milked } & Males & 146 & $82.6^{b}$ & 60.18 & $8-360$ & 39 & 97.5 & 107.75 & $12-650$ \\
\hline & Females & 54 & 104.3 & 85.35 & $8-420$ & 6 & 84.2 & 49.34 & $25-150$ \\
\hline & Total & 200 & 88.5 & 68.35 & $8-420$ & 45 & 95.7 & 101.61 & $12-650$ \\
\hline
\end{tabular}

Descriptive values ( $n$, mean, $S D$, and range), divided by sex.

${ }^{a} p<0.10$.

${ }^{b} p<0.05$

${ }^{c} p<0.01$.

${ }^{d} p<0.001$.

eDifferences between sexes (independent samples $t$-test).

${ }^{t}$ Differences between dairy farmers with and without musculoskeletal symptoms in 2013 (independent samples t-test).

Significant decreases in values between no symptoms and symptoms are marked in green.

The superscript "/" separates the significant levels $(a, b, c, d)$ of the tests with respect to sex (test e) and farmers with and without symptoms (test $f$ ).

milker responses from 199 farm businesses were treated in the present study and were compared with the data collected in 1988 and 2002 (Table 1).

\section{Data Analysis}

Descriptive statistics regarding demographics, working hours, employment, milking systems, herd size, age of farm buildings, and perceived MSSs, represented by number $(n)$, frequency $(\%)$, mean, $\mathrm{SD}$, range, and statistical tendency and significance, are presented by gender and survey year in Tables 2-4; by gender and MSSs/no MSSs in 2013 in Tables 5 and 6; by gender and milking robot/other systems in 2013 in Table 7; and by gender, age, and survey year in Table 8.

For statistical analysis of the results, independent samples $t$-tests, Mann-Whitney $U$ tests, and chi-square analyses were applied using SPSS version 22 (28). If one cell contained an expected count $<5$, Fisher's exact test was used. Otherwise, Pearson's chi-square was calculated. The probability limits for evaluating statistical tendency $\left(^{\mathrm{a}}\right)$ and significance $\left({ }^{\mathrm{b}, c, d}\right)$ were ${ }^{\mathrm{a}} p<0.10,{ }^{\mathrm{b}} p<0.05,{ }^{\mathrm{c}} p<0.01$, and ${ }^{\mathrm{d}} p<0.001$. Significant increases in values between the 2002 and 2013 surveys are marked in red in the tables and significant decreases in green.

\section{Ethical Considerations}

Ethical approval of the Regional Ethical Review Board for studies involving humans was not considered necessary for the survey. The questionnaire was completed anonymously, meaning that no individual or workplace affiliation could be identified. Processing of personal data was performed according to the Personal Data Act (Swedish Code of Statutes, SFS 1998:204), the purpose of which is to protect the individual's integrity. Overall, the national guidelines based on the World Medical Association Declaration of Helsinki concerning research ethics (29), anonymity, voluntariness, confidentiality, and archiving of data were considered and fulfilled.

\section{RESULTS}

\section{Demographics, Working Hours, Employment, Milking Systems, Herd Size, and Age of Farm Buildings}

Of the total of 247 respondents in 2013, 186 (75.3\%) were men and $61(24.7 \%)$ were women.

Compared with the female dairy farmers surveyed, male farmers were on average 7 years older $(\bar{x}=53.5,46.3$; 
TABLE 6 | Description and comparison of dairy farmers with and without musculoskeletal symptoms in 2013.

\begin{tabular}{|c|c|c|c|c|c|c|}
\hline & & & \multicolumn{2}{|c|}{ Symptoms 2013} & \multicolumn{2}{|c|}{ No symptoms 2013} \\
\hline & & & $n$ & $\% e^{e}$ & $n$ & $\% \mathrm{e}^{\mathrm{e} f}$ \\
\hline \multirow[t]{6}{*}{ Employment form } & Males & Employed & 8 & $5.6^{c}$ & 1 & 2.7 \\
\hline & & Self-employed & 135 & 94.4 & 36 & 97.3 \\
\hline & Females & Employed & 12 & 22.2 & 0 & 0.0 \\
\hline & & Self-employed & 42 & 77.8 & 7 & 100.0 \\
\hline & Total & Employed & 20 & 10.2 & 1 & 2.3 \\
\hline & & Self-employed & 177 & 89.8 & 43 & 97.7 \\
\hline \multirow[t]{9}{*}{ Handedness } & Males & Right & 137 & 93.2 & 38 & 97.4 \\
\hline & & Left & 5 & 3.4 & 1 & 2.6 \\
\hline & & Ambidextrous & 5 & 3.4 & 0 & 2.4 \\
\hline & Females & Right & 51 & 94.4 & 6 & 85.7 \\
\hline & & Left & 3 & 5.6 & 1 & 14.3 \\
\hline & & Ambidextrous & 0 & 0.0 & 0 & 0.0 \\
\hline & Total & Right & 188 & 93.5 & 44 & 95.7 \\
\hline & & Left & 8 & 4.0 & 2 & 4.3 \\
\hline & & Ambidextrous & 5 & 2.0 & 0 & 0.0 \\
\hline \multirow[t]{9}{*}{ Housing system } & Males & Tethered & 66 & 46.2 & 17 & 43.6 \\
\hline & & Loose-housing & 68 & 47.6 & 19 & 48.7 \\
\hline & & Both & 9 & 6.3 & 3 & 7.7 \\
\hline & Females & Tethered & 18 & 30.0 & 2 & 33.3 \\
\hline & & Loose-housing & 31 & 62.0 & 4 & 66.7 \\
\hline & & Both & 4 & 8.0 & 0 & 0.0 \\
\hline & Total & Tethered & 84 & 42.9 & 19 & 42.2 \\
\hline & & Loose-housing & 99 & 50.5 & 23 & 51.1 \\
\hline & & Both & 13 & 6.6 & 3 & 6.7 \\
\hline \multirow[t]{6}{*}{ Building date } & Males & -1999 & 90 & $62.9^{a}$ & 18 & $46.2^{/ a}$ \\
\hline & & $2000-$ & 53 & 37.1 & 21 & 53.8 \\
\hline & Females & -1999 & 26 & 48.1 & 3 & 42.9 \\
\hline & & 2000- & 28 & 51.9 & 4 & 57.1 \\
\hline & Total & -1999 & 116 & 58.9 & 21 & 45.7 \\
\hline & & $2000-$ & 81 & 41.1 & 25 & 54.3 \\
\hline
\end{tabular}

Frequency values ( $n$ and \%), divided by sex.

${ }^{a} p<0.10$.

${ }^{b} p<0.05$.

${ }^{c} p<0.01$.

${ }^{d} p<0.001$.

eDifferences between sexes (Pearson chi-square test).

${ }^{f}$ Differences between dairy farmers with and without musculoskeletal symptoms in 2013 (Pearson chi-square test).

Significant increases in values between no symptoms and symptoms are marked in red and significant decreases in green.

The superscript "/" separates the significant levels ( $a, b, c, d)$ of the tests with respect to sex (test e) and farmers with and without symptoms (test $f$ ).

$p=0.000)$, had worked 11 years longer as a dairy farmer $(\bar{x}=32.6,21.8 ; p=0.000)$, and worked $6 \mathrm{~h}$ more per week $(\bar{x}=43.9,37.9 ; p=0.016)$ (Table 2$)$.

Both male and female farmers had increased their working hours, by 3 and $4 \mathrm{~h} /$ week, respectively, in 2013 compared with 2002 (males $\bar{x}=43.9,40.7 ; p=0.016$; females $\bar{x}=37.9$, 33.9; $p=0.055)$. The men in 2013 were about $3 \mathrm{~cm}$ taller and weighed about $2 \mathrm{~kg}$ more than the men in 2002 (Table 2). Each male milked on average 30 cows in 1988, 44 cows in 2002, and 86 cows in 2013. The increase between years was significant $(p=0.000$ and $p=0.000$, respectively). The corresponding number of cows milked by female farmers in 1988, 2002, and 2013 was 29, 60, and 102 , respectively (difference $p=0.000$ and $p=0.000$, respectively) (Table 2).

Women were more frequently farm employees (rather than managers/owners) than their male colleagues in 2013 (19.7 vs. $5.0 \% ; p=0.000$ ) (Table 3).
In 1988, almost all farmers used a tethered system and only $4.1 \%$ of male farmers worked with a loose-housing system. This figure increased to $25.9 \%$ in 2002 and $54.4 \%$ in 2013 ( $p=0.000$ and $p=0.000$, respectively). The corresponding increase for female farmers was from $1.8 \%$ in 1988 to $28.5 \%$ in 2002 and $66.1 \%$ in 2013 ( $p=0.000$ and $p=0.000$, respectively) (Table 3).

About half $(50.7 \%)$ of the farmers who stated that they used a loose-housing system had a robotic milking system.

In 2013 , more than $40 \%$ of men and $50 \%$ of women worked in farm buildings built in 2000 or later (Table 3).

\section{Musculoskeletal Symptoms}

About $79.0 \%$ of men and $88.5 \%$ of women reported MSSs at some time in 2013 , whereas in 2002, $83.4 \%$ of men and $89.7 \%$ of women indicated MSSs. This change was not significant $(p=0.187$ and $p=0.791$ for men and women, respectively). As in 2002, in 2013, men more often reported symptoms in lower back (53.2\%), 
TABLE 7 | Frequency in 2013 of perceived symptoms [number $(n)$ and \%] in the musculoskeletal system at some time during the past 12 months among dairy farmers, divided by sex, working with a milking robot and other systems.

\begin{tabular}{|c|c|c|c|c|c|}
\hline & & \multicolumn{2}{|c|}{ Milking robot } & \multicolumn{2}{|c|}{ Other system } \\
\hline & & $n$ & $\%$ & $n$ & $\%^{e / f}$ \\
\hline \multirow[t]{3}{*}{ Neck } & Males & 10 & 19.6 & 39 & 29.8 \\
\hline & Females & 5 & 26.3 & 15 & 37.5 \\
\hline & Total & 15 & 21.4 & 54 & 31.6 \\
\hline \multirow[t]{3}{*}{ Shoulders } & Males & 14 & $27.5^{\mathrm{a}}$ & 54 & $41.2^{\mathrm{c} / \mathrm{a}}$ \\
\hline & Females & 10 & 52.6 & 27 & 67.5 \\
\hline & Total & 24 & 34.3 & 81 & $47.4^{/ a}$ \\
\hline \multirow[t]{3}{*}{ Elbows } & Males & 10 & 19.6 & 18 & 13.7 \\
\hline & Females & 3 & 15.8 & 6 & 15.0 \\
\hline & Total & 13 & 18.6 & 24 & 14.0 \\
\hline \multirow[t]{3}{*}{ Wrists/hands } & Males & 8 & $15.7^{b}$ & 18 & $13.7^{\mathrm{d}}$ \\
\hline & Females & 9 & 47.4 & 21 & 52.5 \\
\hline & Total & 17 & 24.3 & 39 & 22.8 \\
\hline \multirow[t]{3}{*}{ Upper back } & Males & 4 & 7.8 & 13 & $9.9^{b}$ \\
\hline & Females & 2 & 10.5 & 10 & 25.5 \\
\hline & Total & 6 & 8.6 & 23 & 13.5 \\
\hline \multirow[t]{3}{*}{ Lower back } & Males & 26 & 51.0 & 70 & 53.4 \\
\hline & Females & 5 & 26.3 & 25 & $62.5^{/ b}$ \\
\hline & Total & 31 & 44.3 & 95 & 55.6 \\
\hline \multirow[t]{3}{*}{ Hips } & Males & 9 & 17.6 & 38 & 29.0 \\
\hline & Females & 4 & 21.1 & 10 & 25.0 \\
\hline & Total & 13 & 18.6 & 48 & 28.1 \\
\hline \multirow[t]{3}{*}{ Knees } & Males & 21 & 41.2 & 41 & 31.3 \\
\hline & Females & 6 & 31.6 & 15 & 35.0 \\
\hline & Total & 27 & 38.6 & 55 & 32.2 \\
\hline \multirow[t]{3}{*}{ Feet } & Males & 7 & 13.7 & 21 & 15.3 \\
\hline & Females & 3 & 15.8 & 9 & 22.5 \\
\hline & Total & 10 & 14.3 & 29 & 17.0 \\
\hline \multirow[t]{3}{*}{ Any body part } & Males & 39 & 76.5 & 104 & 79.4 \\
\hline & Females & 17 & 89.5 & 36 & 90.0 \\
\hline & Total & 56 & 80.0 & 140 & 81.9 \\
\hline
\end{tabular}

${ }^{a} p<0.10$.

${ }^{b} p<0.05$.

${ }^{c} p<0.01$.

${ }^{d} p<0.001$.

¿Differences between sexes (Pearson chi-square test).

${ }^{t}$ Differences between dairy farmers working with and without milking robot in 2013 (Pearson chi-square test).

Significant decreases in values between symptoms in other symptoms and symptoms in robot systems are marked in green.

The superscript "/" separates the significant levels (a, b, c, d) of the tests with respect to sex (test e) and farmers with and without milking robot systems (test f f).

shoulders (38.2\%), and knees (34.4\%). The women surveyed in 2013 most often reported discomfort in shoulders (62.3\%), lower back (50.8), and wrists/hands (49.2\%). This pattern was the same as in 2002. No significant change in the frequency of MSSs in 2013 compared with 2002 was observed in the three most frequent body regions for either men or women (Table 4).

The men in 2013 who stated that they had experienced trouble in some body region worked an average of $6 \mathrm{~h}$ less per week than the men who did not report any such trouble (Table 5). In addition, they worked more often in older buildings (Table 6).

Both men and women reported symptoms at some time in 2013 equally frequently, about 80 and $90 \%$ respectively, regardless of whether they worked in a tethered system or loose-housing system (Table 6). However, the men who worked with a milking robot reported significantly fewer symptoms in the shoulders than the men who worked in other systems. The women who worked with a milking robot reported fewer problems in the lower back (Table 7).

The younger dairy farmers ( $\leq 35$ years) in 2013 more often reported discomfort in the shoulders $(p=0.054)$, elbows $(p=0.020)$, lower back $(p=0.058)$, and feet $(p=0.076)$ compared with 2002, while the older farmers (55 years and older) reported fewer problems with the neck $(p=0.034)$, shoulders $(p=0.084)$, elbows $(p=0.005)$, wrists/hands $(p=0.004)$, and knees $(p=0.081)$ (Table 8).

\section{Aids and Facilities}

In the tethered systems, the following facilities were used: milking stool (48.5\%) (Figure 1), "kangaroo bag" [a belt to wear containing a bottle holder and large bags for carrying milking towels (28.2\%)], rubber mat on the floor (33.0\%) (Figure 2), milking rail (36.9\%) (Figure 3), and automatic cluster removal $(32.0 \%)$ (Figure 4). In loose-housing systems, farmers used kangaroo bag (3.3\%), rubber mat on the floor (7.4\%), automatic cluster removal (39.3\%), height-adjustable floor (18.0\%) (Figure 5), and support arm (10.7\%) (Figure 6).

\section{Manure and Feed Handling}

In loose-housing systems, both manure management and feed handling were more mechanized than in tethered systems. About $86 \%$ used a pressure washer in loose housing, compared with $83 \%$ in tethered systems.

\section{Health Problems and Injuries}

Approximately $17 \%$ of the dairy farmers surveyed indicated that they had health problems other than MSSs arising from their work in tethered systems, compared with $9 \%$ in loose-housing systems. Common symptoms were asthma, allergies, and rashes, but also disorders of the respiratory system such as sneezing, coughing, and colds. The dairy farmers also indicated experiencing fatigue and stress.

A total of $32.8 \%$ of dairy farmers had suffered some form of injury at work. Among those who worked in tethered systems, $40.8 \%$ had experienced an injury, compared with $30.7 \%$ in loose-housing systems. Animal-related injuries dominated, such as kicks, trampling, crushing, and butting by the animals. Fall injuries also occurred in both systems.

\section{Strenuous Duties}

Overall, farmers working in tethered systems reported that feed/ silage management and milking itself were the most strenuous tasks, while farmers working in loose-housing systems reported cleaning and feeding/handling silage as the most exhausting.

\section{Job Satisfaction}

For farmers using the tethered system, working with the animals and the milking itself gave the most job satisfaction, while for those working in loose-housing systems, working with the animals and calves gave the most job satisfaction. 
TABLE 8 | Frequency in 2013, 2002, and 1988 of perceived symptoms [numbers (n) and \%] in the musculoskeletal system at some time during the past 12 months among dairy farmers, divided by sex and age.

\begin{tabular}{|c|c|c|c|c|c|c|c|c|c|c|c|c|c|c|c|c|c|c|c|}
\hline & & \multicolumn{6}{|c|}{2013} & \multicolumn{6}{|c|}{2002} & \multicolumn{6}{|c|}{1988} \\
\hline & & \multicolumn{2}{|c|}{$\leq 35$ years } & \multicolumn{2}{|c|}{$36-54$ years } & \multicolumn{2}{|c|}{$\geq 55$ years } & \multicolumn{2}{|c|}{$\leq 35$ years } & \multicolumn{2}{|c|}{$36-54$ years } & \multicolumn{2}{|c|}{$\geq 55$ years } & \multicolumn{2}{|c|}{$\leq 35$ years } & \multicolumn{2}{|c|}{$36-54$ years } & \multicolumn{2}{|c|}{$\geq 55$ years } \\
\hline & & $n$ & $\%$ & $n$ & $\%$ & $n$ & $\%$ & $n$ & $\%^{\mathrm{e}}$ & $n$ & $\%^{\mathrm{e}}$ & $n$ & $\%^{\mathrm{e}}$ & $n$ & $\%^{f}$ & $n$ & $\%^{f}$ & $n$ & $\%^{f}$ \\
\hline \multirow[t]{3}{*}{ Neck } & Males & 4 & 30.8 & 22 & 31.9 & 24 & 23.5 & 14 & 24.1 & 71 & 30.1 & 53 & $34.2^{\mathrm{a}}$ & 22 & $11.4^{b}$ & 118 & $22.6^{b}$ & 89 & $24.8^{b}$ \\
\hline & Females & 7 & 43.8 & 9 & 32.1 & 4 & 23.5 & 9 & 39.1 & 44 & 40.0 & 18 & 36.7 & 20 & 23.3 & 69 & 31.8 & 23 & 27.4 \\
\hline & Total & 11 & 37.9 & 31 & 32.0 & 28 & 23.5 & 23 & 28.4 & 115 & 33.2 & 71 & $34.8^{b}$ & 42 & $15.1^{c}$ & 187 & $25.3^{c}$ & 112 & $25.3^{b}$ \\
\hline \multirow[t]{3}{*}{ Shoulders } & Males & 5 & 38.5 & 26 & 37.7 & 40 & 39.2 & 18 & 30.0 & 93 & 39.9 & 84 & $53.2^{\mathrm{b}}$ & 38 & $19.7^{a}$ & 187 & 35.8 & 141 & $39.3^{c}$ \\
\hline & Females & 12 & 75.0 & 14 & 50.0 & 12 & 70.6 & 14 & 58.3 & 65 & 60.7 & 27 & 55.1 & 35 & 40.7 & 101 & $46.5^{b}$ & 30 & $35.7^{b}$ \\
\hline & Total & 17 & 58.6 & 40 & 41.2 & 52 & 43.7 & 32 & $38.1^{a}$ & 158 & 46.5 & 111 & $53.6^{a}$ & 73 & $26.2^{\mathrm{b}}$ & 288 & $38.9^{b}$ & 171 & $38.6^{d}$ \\
\hline \multirow[t]{3}{*}{ Elbows } & Males & 2 & 15.4 & 14 & 20.3 & 12 & 11.8 & 2 & 3.4 & 51 & 21.3 & 39 & $25.2^{c}$ & 13 & 6.8 & 106 & 20.3 & 70 & 19.6 \\
\hline & Females & 2 & 12.5 & 5 & 17.9 & 2 & 11.8 & 0 & 0.0 & 39 & $36.4^{\mathrm{a}}$ & 11 & 22.9 & 10 & 11.6 & 60 & 27.6 & 17 & 20.2 \\
\hline & Total & 4 & 13.8 & 19 & 19.6 & 14 & 11.8 & 2 & $2.4^{b}$ & 90 & 26.0 & 50 & $24.6^{c}$ & 23 & $8.3^{a}$ & 166 & 22.4 & 87 & 19.7 \\
\hline \multirow[t]{3}{*}{ Wrists/hands } & Males & 2 & 15.4 & 14 & 20.3 & 12 & 11.8 & 13 & 22.8 & 55 & 23.0 & 43 & $27.4^{c}$ & 31 & 16.1 & 78 & $14.9^{c}$ & 63 & $17.6^{b}$ \\
\hline & Females & 10 & 62.5 & 12 & 42.9 & 8 & 47.1 & 9 & 37.5 & 52 & 47.7 & 22 & 44.9 & 29 & 33.7 & 75 & $34.6^{b}$ & 27 & 32.1 \\
\hline & Total & 12 & 41.4 & 26 & 26.8 & 20 & 16.8 & 22 & 27.2 & 107 & 30.7 & 65 & $31.6^{c}$ & 60 & 21.6 & 153 & $20.7^{d}$ & 90 & $20.4^{c}$ \\
\hline \multirow[t]{3}{*}{ Upper back } & Males & 2 & 15.4 & 7 & 10.1 & 8 & 7.8 & 9 & 16.1 & 28 & 12.0 & 13 & 8.6 & 18 & 9.4 & 42 & $8.0^{\mathrm{a}}$ & 31 & 8.7 \\
\hline & Females & 4 & 25.0 & 6 & 21.4 & 2 & 11.8 & 3 & 12.5 & 19 & 17.4 & 6 & 12.2 & 10 & 11.6 & 29 & 13.4 & 8 & 9.6 \\
\hline & Total & 6 & 20.7 & 13 & 13.4 & 10 & 8.4 & 12 & 15.0 & 47 & 13.7 & 19 & 9.5 & 28 & 10.1 & 71 & $9.6^{b}$ & 39 & 8.9 \\
\hline \multirow[t]{3}{*}{ Lower back } & Males & 8 & 61.5 & 43 & 62.3 & 48 & 47.1 & 25 & 47.1 & 131 & 54.8 & 89 & 56.0 & 92 & 48.4 & 305 & 58.3 & 197 & 55.0 \\
\hline & Females & 10 & 62.5 & 15 & 53.6 & 6 & 35.3 & 10 & 41.7 & 55 & 50.9 & 20 & 60.0 & 37 & 43.0 & 112 & 51.6 & 39 & 46.4 \\
\hline & Total & 18 & 62.1 & 58 & 59.8 & 54 & 45.4 & 35 & $41.7^{a}$ & 186 & 53.6 & 109 & 52.2 & 129 & 46.7 & 417 & 56.4 & 236 & 53.4 \\
\hline \multirow[t]{3}{*}{ Hips } & Males & 2 & 15.4 & 18 & 26.1 & 30 & 29.4 & 9 & 15.3 & 68 & 28.6 & 46 & 30.7 & 21 & 11.0 & 137 & 26.2 & 113 & 31.6 \\
\hline & Females & 1 & 6.2 & 8 & 28.6 & 5 & 29.4 & 3 & 12.5 & 38 & 35.5 & 21 & 42.0 & 12 & 14.0 & 63 & 29.0 & 25 & 29.8 \\
\hline & Total & 3 & 10.3 & 26 & 26.8 & 35 & 29.4 & 12 & 14.5 & 106 & 30.7 & 67 & 33.5 & 33 & 11.9 & 200 & 27.0 & 138 & 31.2 \\
\hline \multirow[t]{3}{*}{ Knees } & Males & 5 & 38.5 & 27 & 39.1 & 32 & 31.4 & 20 & 33.9 & 79 & 33.3 & 74 & $45.7^{b}$ & 72 & 37.3 & 200 & 38.3 & 157 & 43.9 \\
\hline & Females & 5 & 31.2 & 8 & 28.6 & 8 & 47.1 & 6 & 25.0 & 36 & 33.3 & 18 & 36.0 & 22 & 25.6 & 83 & 38.2 & 40 & 47.6 \\
\hline & Total & 10 & 34.5 & 35 & 36.1 & 40 & 33.6 & 26 & 31.3 & 115 & 33.3 & 92 & $43.4^{\mathrm{a}}$ & 94 & 33.7 & 283 & 38.3 & 197 & 44.6 \\
\hline \multirow[t]{3}{*}{ Feet } & Males & 2 & 15.4 & 13 & 18.8 & 13 & 12.7 & 6 & 10.2 & 28 & 11.7 & 31 & 20.4 & 17 & 8.8 & 63 & 12.0 & 33 & $9.2^{d}$ \\
\hline & Females & 4 & 25.0 & 6 & 21.4 & 2 & 11.8 & 1 & 4.2 & 25 & 23.4 & 9 & 17.6 & 4 & 4.7 & 38 & 17.5 & 18 & 21.7 \\
\hline & Total & 6 & 20.7 & 19 & 19.6 & 15 & 12.6 & 7 & $8.4^{a}$ & 53 & 15.3 & 40 & 19.7 & 21 & 7.5 & 101 & 13.6 & 51 & $11.6^{c}$ \\
\hline \multirow[t]{3}{*}{ Any body part } & Males & 11 & 84.6 & 56 & 81.2 & 80 & 78.4 & 50 & 82.0 & 200 & 82.3 & 144 & 85.2 & 140 & 72.5 & 441 & 84.3 & 291 & 81.3 \\
\hline & Females & 14 & 87.5 & 25 & 89.3 & 15 & 88.2 & 21 & 87.5 & 99 & 90.8 & 44 & 88.0 & 70 & 81.4 & 189 & 87.1 & 67 & 79.9 \\
\hline & Total & 25 & 86.2 & 81 & 83.5 & 95 & 79.8 & 71 & 83.5 & 299 & 84.9 & 188 & 85.8 & 210 & 75.3 & 630 & 85.1 & 358 & 81.0 \\
\hline
\end{tabular}

${ }^{a} p<0.10$

${ }^{b} p<0.05$.

${ }^{c} p<0.01$.

${ }^{d} p<0.001$.

${ }^{e}$ Differences between dairy farmers in 2013 and 2002 (Pearson chi-square test).

${ }^{t}$ Differences between dairy farmers in 2002 and 1988 (Pearson chi-square test).

Significant increases in values between the 2002 and 2013 surveys are marked in red and significant decreases in green.

\section{DISCUSSION}

The results of this most recent survey show that milking dairy cows is still associated with a high incidence of MSSs, as found previously among dairy farmers with smaller herd size operations $(8,16,30)$ and operations with larger herd size (9).

No statistically significant reduction in the total number of complaints in 2013 was observed compared with 2002, despite the technological developments that have taken place over the last 20 years. A concerning finding was that young dairy farmers ( $\leq 35$ years) more frequently reported symptoms than the corresponding young dairy farmers in 2002. However, the dairy farmers who were 55 and older reported fewer complaints than in 2002. This may be because older farmers with health complaints had stopped milking due to their problems in the interim and that only the healthy elderly remained in the profession (the so-called healthy worker effect). This effect was also observed in the 2002 study, where more than $20 \%$ of those who had stopped milking cited occupational health reasons for this (15). The effect has also been reported in other studies on musculoskeletal disorders among farmers (31) and among pig keepers with lung problems (32).

One advantage of the present study and of the previous two surveys was the availability of a relatively large body of material 


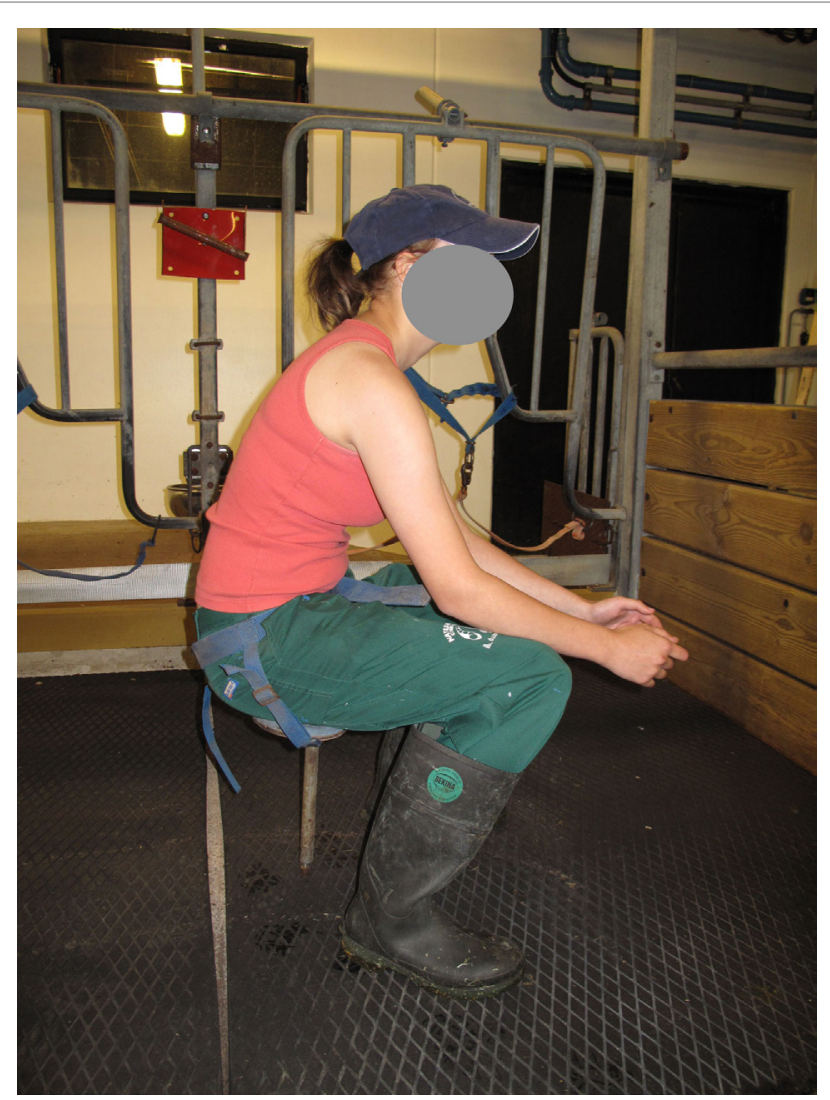

FIGURE 1 | Milking stool. (Christina Lunner Kolstrup.

collected using the same validated and standardized questionnaire for assessment of MSSs, which made it possible to study trends in the prevalence of MSSs among Scanian dairy farmers. However, it was not possible to grade the severity or the type of MSSs, since the relevant questions in the questionnaire only asked if the respondents had at some time experienced MSSs, and did not enquire about the severity or the type of symptoms. For this, more in-depth studies are needed. Moreover, it was not possible to establish causality between MSSs and the risk factors studied, since the present study and the previous surveys were designed as cross-sectional studies where variables were measured at the same time. Therefore, we could not establish whether the MSSs or exposure to the risk factors came first.

In addition to MSSs, dairy farmers suffer work-related injuries. In 2013, approximately one-third of the dairy farmers in Scania reported that they had been injured during work at some time. A previous study of injuries in agriculture showed that on 15\% of Swedish dairy farms, at least one accident occurred in 2004 (33). Preliminary results from an ongoing study on injuries in agriculture in 2013 (Pinzke and Lundqvist, manuscript) show no reduction in the number of injuries compared with 2004 when the number of hours worked is taken into account.

Several studies have shown that compared with milking in parlor systems, milking in tethered stall systems involves more loading work postures and more handling of manual materials,

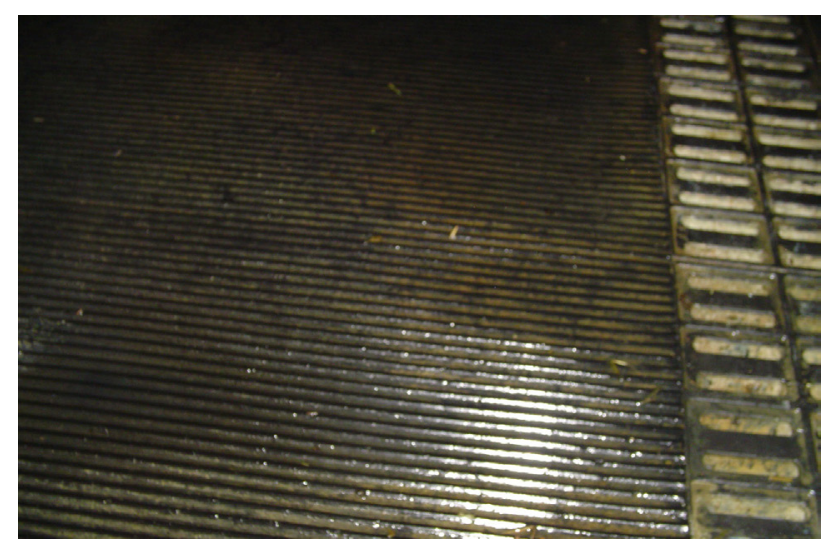

FIGURE 2 | Rubber matting. (Stefan Pinzke.

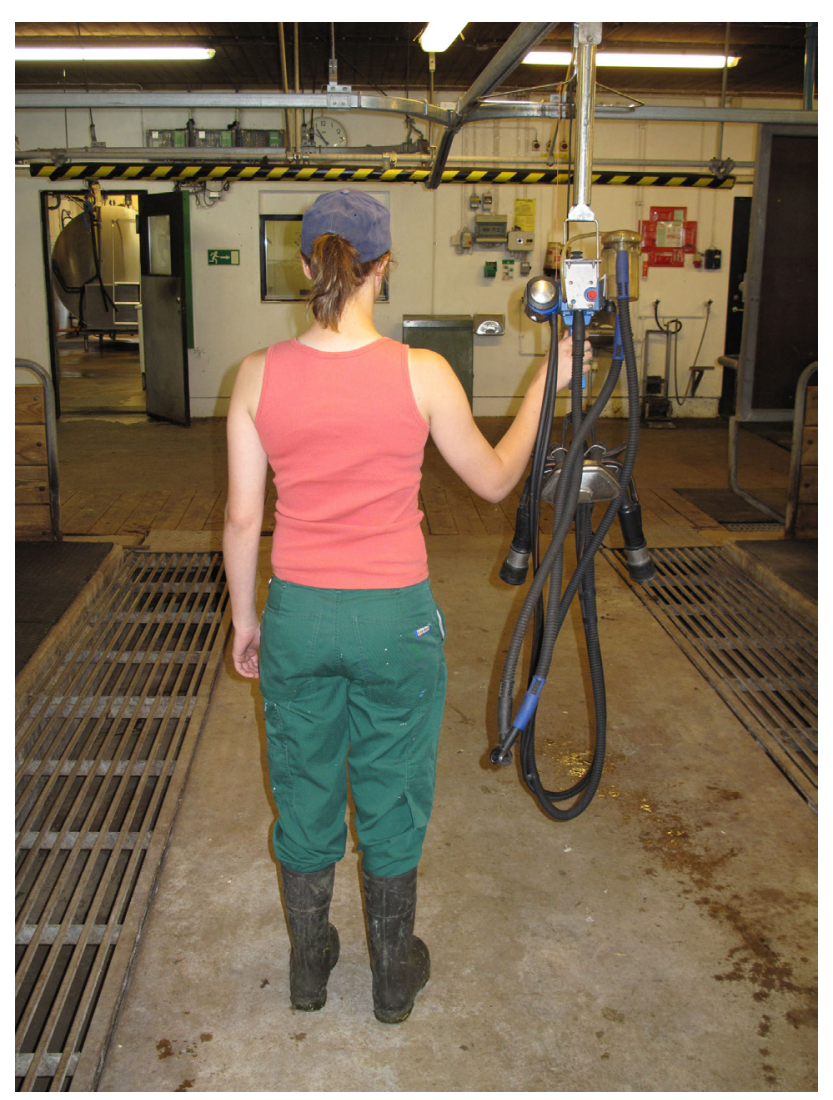

FIGURE 3 | Milking rail. @Christina Lunner Kolstrup.

which are risk factors for MSSs in the shoulders and lower part of the body. On the other hand, milking in loose-housing systems involves repetitive and monotonous work, which is a risk factor for developing MSSs, especially in the upper extremities $(5,8-10$, 14-20). As this study shows, milkers still reported an equally high frequency of MSSs as in the past, regardless of whether they worked in tethered or parlor systems. However, those working 


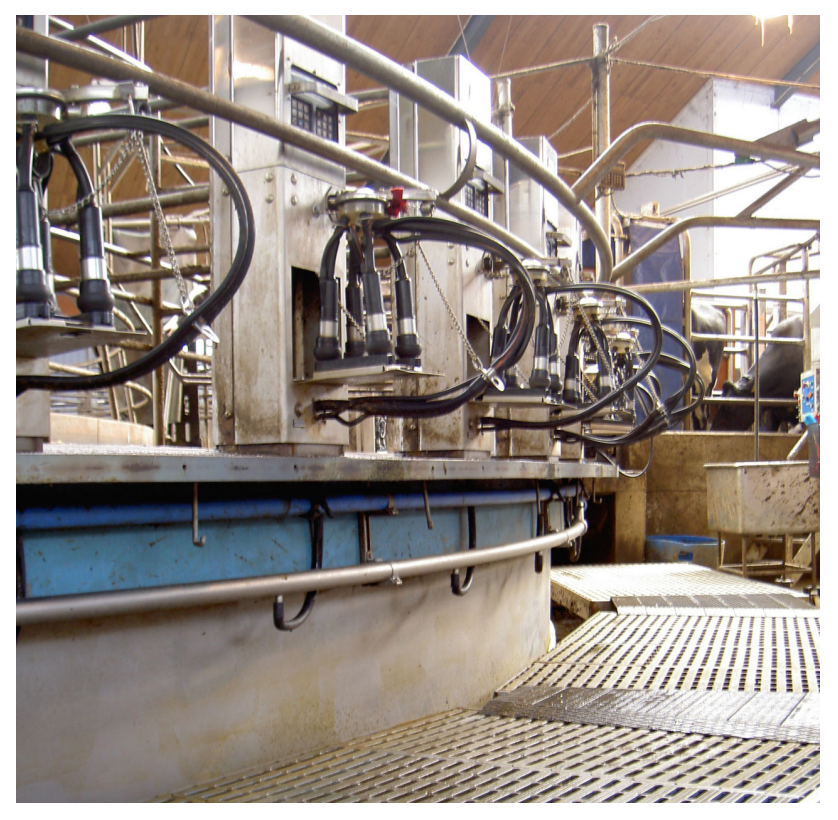

FIGURE 4 | Automatic cluster removal. @Christina Lunner Kolstrup, Stefan Pinzke.

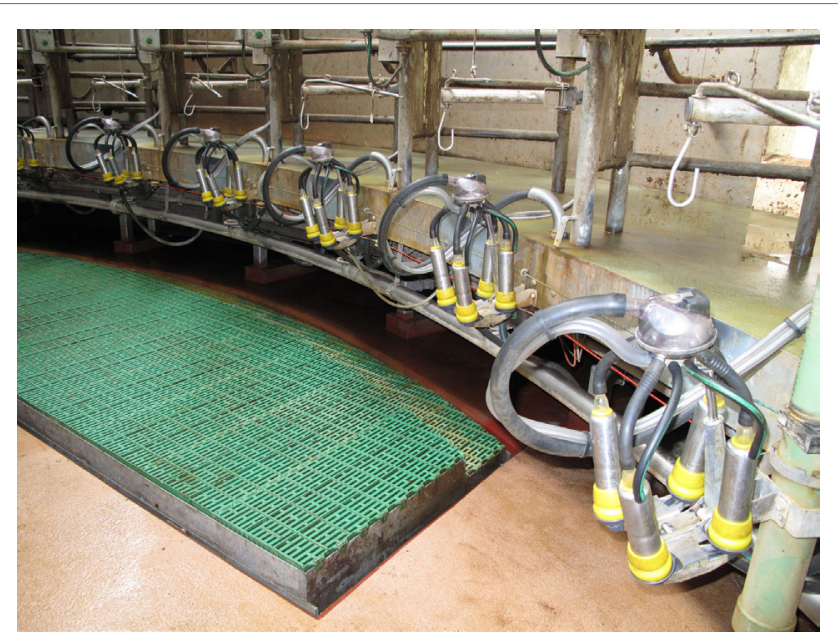

FIGURE 5 | Adjustable floor. @Christina Lunner Kolstrup, Stefan Pinzke.

with milking robot systems in 2013 reported fewer MSSs overall, especially in shoulders (men) and lower back (women), compared with those working with other systems. An explanation for this is of course that the robot, instead of the milker, performs most of the heavy, repetitive, and one-sided milking tasks. A reduction in the risk of musculoskeletal problems with robotic milking compared with conventional milking has also been reported in other studies (34). Just over $28 \%$ of the Scanian dairy farmers surveyed in 2013 responded that they worked with robotic milking systems. This corresponds fairly well with the incidence of robotic milking (32\%) throughout the country (35).

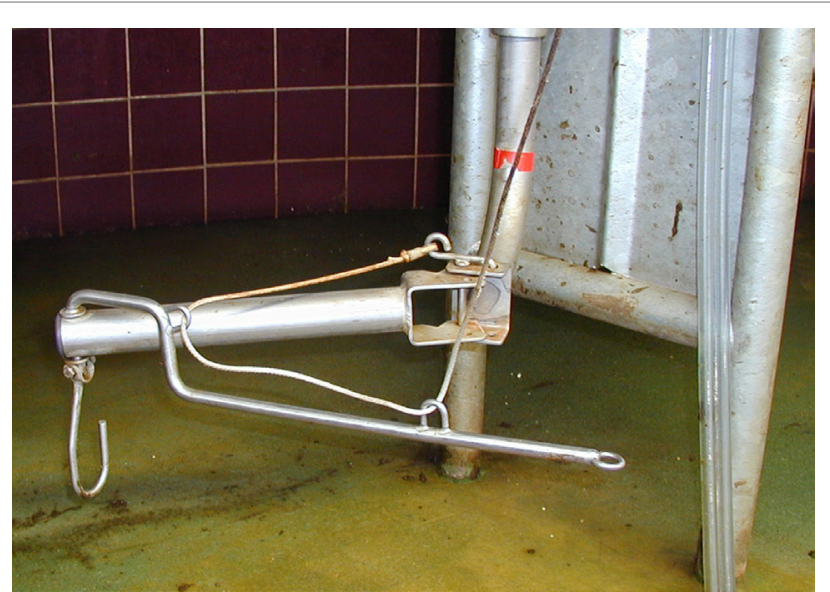

FIGURE 6 | Support arm. CChristina Lunner Kolstrup, Stefan Pinzke.

Many developments have been made in technical aids and the design of milking systems in order to reduce workloads and prevent musculoskeletal disorders when milking cows $(10,36)$. In an EU project where SLU was one partner (37), several good practices were observed on farm visits across Belgium, Poland, Sweden, and UK, e.g., installation of milking rails in tethered houses to facilitate transport of milking equipment and adjusting the floor to the height of the farmer in loose-housing systems. Use of perforated rubber matting on existing floors in parlors is another example of good practice that aims to reduce the physical load on the lower limbs and reduce fatigue. Other solutions are designed for specific tasks during milking in parlors; e.g., when cleaning udders, central placement of a basket for drying papers or cloths on a cart reduces both walking distance and exposure to awkward back postures for the milking staff. Installation of a support arm can reduce the workload when attaching the milking cluster to the cow. The use of lightweight clusters and tubes also reduces the load. Instead of using a dip cup for teat dipping, the farmer can spray the cow's teats with disinfectant, thus reducing the reach distance during work. Despite these solutions in place on existing farms, not enough research has been done on specific ergonomic interventions in milking parlors.

Some studies have attempted to find the optimum working height for dairy farmers during milking. Jakob et al. (38) found that the optimum working height when attaching teat cups to the udder is having the cow's teats at shoulder level, while Stål and Pinzke (39) found that the ideal working posture is when the farmer's elbow height is about $30 \mathrm{~cm}$ above the floor where the cow is standing.

The technical aids described above, such as an adjustable floor, support arm, and lightweight clusters, can improve the loading conditions for the farmer if they are applied correctly. However, because of the wide variation in the body composition of cows and differences in the body height of dairy farmers, there is still no technical solution to ensure an optimum working position for all workers at all times. 
This study showed that milkers in 2013 were still reporting as many MSSs as 10 years earlier, despite the technical solutions that have been introduced in different milking systems to reduce risk factors for developing MSSs, such as awkward working postures and physical workload. At the same time, exposure to other risk factors has increased, e.g., weekly working hours, number of milking cows, and a higher proportion of working in loose-housing systems, where milkers are exposed to monotonous and repetitive work. Thus, there is a need for continued efforts and research to improve the ergonomic conditions on dairy farms in order to make milking work more attractive, with fewer musculoskeletal problems, especially for younger dairy farmers who are currently working with milking, but also to attract new recruits.

\section{REFERENCES}

1. Eurostat. Milk and Dairy Production Statistics. Statistics in Focus 17/2013. European Statistical System. (2013). Available from: http://ec.europa. eu/eurostat/statistics-explained/index.php/Archive:Milk_and_dairy_ production_statistics

2. USDA. Dairy Cattle and Milk Production. 2012 Census of Agriculture Highlights, ACH12-14/October 2014. United States Department of Agriculture, National Agricultural Statistics Service (2014). Available from: http://www.agcensus. usda.gov/Publications/2012/Online_Resources/Highlights/Dairy_Cattle_ Milk_Prod/Dairy_Cattle_and_Milk_Production_Highlights.pdf

3. MacDonald JM, O'Donoghue EJ, McBride WD, Nehring RF, Sandretto CL, Mosheim R. Profits, Costs, and the Changing Structure of Dairy Farming. Economic Research Report No. 47. United States Department of Agriculture, Economic Research Service (2007). Available from: http://www.ers.usda.gov/ media/188030/err47_1_.pdf

4. Clark DA, Caradus JR, Monaghan RM, Sharp P, Thorrold BS. Issues and options for future dairy farming in New Zealand. New Zeal J Agr Res (2007) 50:203-21. doi:10.1080/00288230709510291

5. Douphrate DI, Nonnenmann MW, Rosecrance JC. Ergonomics in industrialized dairy operations. JAgromed (2009) 14:406-12. doi:10.1080/10599240903260444

6. Nonnenman M. Musculoskeletal Symptoms and Exposure to Knee Flexion Among Dairy Farmers [Doctoral Dissertation]. Iowa City (IA): The University of Iowa (2005).

7. Douphrate DI, Hagevoort GR, Nonnenmann MW, Lunner Kolstrup C, Reynolds SJ, Jakob M, et al. The dairy industry: a brief description of production practices, trends, and farm characteristics around the world. J Agromed (2013) 18:187-97. doi:10.1080/1059924X.2013.796901

8. Kolstrup C, Stål M, Pinzke S, Lundqvist P. Ache, pain, and discomfort: the reward for working with many cows and sows? J Agromed (2006) 11:45-55. doi:10.1300/J096v11n02_08

9. Douphrate DI, Gimeno D, Nonnenmann MW, Hagevoort R, Rosas-Goulart C, Rosecrance JC. Prevalence of work-related musculoskeletal symptoms among US large-herd dairy parlor workers. Am J Ind Med (2014) 57:370-9. doi:10.1002/ajim.22286

10. Douphrate D, Lunner Kolstrup C, Nonnenmann M, Jakob M, Pinzke S. Ergonomics in modern dairy practice: a review of current issues and research needs. J Agromed (2013) 18:198-209. doi:10.1080/1059924X.2013.796900

11. Short SD. Structure, Management, and Performance Characteristics of Specialized Dairy Farm Businesses in the United States (Agriculture Handbook 720). Washington, DC: USDA ERS (2000).

12. Jacobs JA, Siegford JM. Invited review: the impact of automatic milking systems on dairy cow management, behavior, health, and welfare. J Dairy Sci (2012) 95:2227-47. doi:10.3168/jds.2011-4943

13. Oostra $\mathrm{H}$. The effects of feeding frequency on waiting time, milking frequency, cubicle and feeding fence utilization for cows in an automatic milking system. Acta Agric Scand A Anim Sci (2007) 55:158-65. doi:10.1080/09064700500488985

14. Gustafsson B, Pinzke S, Isberg P. Musculoskeletal symptoms in Swedish dairy farmers. Swed J Agric Res (1994) 24:177-88.

\section{AUTHOR CONTRIBUTIONS}

The author planned the study, carried out the data collection, analyzed the data, and wrote the article.

\section{ACKNOWLEDGMENTS}

This study was financially supported by grants from the SLO Foundation (H122-0043-SLO) (Stockholm, Sweden) and administered by the Royal Swedish Academy of Agriculture and Forestry (Stockholm, Sweden). I am also indebted to the Swedish Board of Agriculture for supplying the addresses of the dairy farmers and distributing the questionnaires.

15. Pinzke S. Changes in working conditions and health among dairy farmers in southern Sweden - a 14-year follow-up. Ann Agric Environ Med (2003) 10:185-95.

16. Nonnenmann MW, Anton D, Gerr F, Merlino L, Donham K. Musculoskeletal symptoms of the neck and upper extremities among Iowa dairy farmers. Am J Ind Med (2008) 51:443-51. doi:10.1002/ajim.20582

17. Pinzke S, Stål M, Hansson GA. Physical workload on upper extremities in various operations during machine milking. Ann Agric Environ Med (2001) 8:63-70.

18. Stål M, Hansson GA, Moritz U. Upper extremity muscular load during machine milking. Int J Ind Ergon (2000) 26:9-17. doi:10.1016/ S0169-8141(99)00059-1

19. Stål M, Hansson GA, Moritz U. Wrist positions and movements as possible risk factors during machine milking. Appl Ergon (1999) 30:527-33. doi:10.1016/ S0003-6870(99)00015-0

20. Douphrate DI, Fethke NB, Nonnenmann MW, Rosecrance JC, Reynolds SJ. Full shift arm inclinometry among dairy parlor workers: a feasibility study in a challenging work environment. Appl Ergon (2011) 43:604-13. doi:10.1016/j.apergo.2011.09.007

21. Statistics Sweden. Jordbruksstatistisk årsbok 1991 [Yearbook of Agricultural Statistics 1991]. Stockholm: Statistics Sweden (1991).

22. Statistics Sweden. Jordbruksstatistisk årsbok 2001 [Yearbook of Agricultural Statistics 2001]. Örebro: Statistics Sweden (2001).

23. Statistics Sweden. Jordbruksstatistisk årsbok 2011 [Yearbook of Agricultural Statistics 2011]. Örebro: Statistics Sweden (2011).

24. Statistics Sweden. Jordbruksstatistisk årsbok 2014 [Yearbook of Agricultural Statistics 2014]. Örebro: Statistics Sweden (2014).

25. Kuorinka I, Jonsson B, Vinterberg H. Standardized Nordic questionnaires for the analysis of musculoskeletal symptoms. Appl Ergon (1987) 18:233-7. doi:10.1016/0003-6870(87)90010-X

26. Lundqvist P. Psychosocial Factors in the Working Environment of Young Swedish Farmers with Milk Production. Working Environment in Farm Buildings. Diss. Rapport 58. Lund: LBT (1988). p. 187-222.

27. Gustafsson B, Lundqvist P. Psychosocial factors in the working environment of Swedish dairy farmers. In: Annewink E, Owing RK, Vos HW, editors. Farm Planning. Labour and Labour Conditions. Proceedings XXV CIOSTA-CIGR Congress. Wageningen (1993). p. 145-50.

28. IBM. SPSS Statistics for Windows, Version 22.0. Armonk, NY: IBM Corp (2013).

29. World Medical Association. Declaration of Helsinki: Ethical Principles for Medical Research Involving Human Subjects. (2016). Available from: http:// www.wma.net/en/30publications/10policies/b3/. Retrieved May 2016.

30. Lunner Kolstrup C. Work-related musculoskeletal discomfort of dairy farmers and employed workers. JOccup Med Toxicol (2012) 7:1-9. doi:10.1186/1745-6673-7-23

31. Osborne A, Blake C, McNamara J, Meredith D, Phelan J, Cunningham C. Musculoskeletal disorders among Irish farmers. Occup Med (2010) 60:598-603. doi:10.1093/occmed/kqq146

32. Chénard L, Senthilselvan A, Grover VK, Kirychuk SP, Lawson JA, Hurst TS, et al. Lung function and farm size predict healthy worker effect in swine farmers. Chest (2007) 131:245-54. doi:10.1378/chest.05-2238 
33. Pinzke S, Lundqvist P. Occupational accidents in Swedish agriculture. Agric Eng Res (2007) 13:159-65.

34. Geng Q, Gustavsson M, Torén A. Automatiska mjölkningssystem - en väg till bättre arbetsmiljö i mjölkproduktionen [Automatic Milking System - A Way to Better Working Environment in Dairy Farms]. Uppsala: Swedish Institute of Agricultural and Environmental Engineering (2006). JTIReport 350.

35. Bergman K, Rabinowicz E. Adoption of the Automatic Milking System by Swedish Milk Producers. AgriFood Economics Working Paper 2013:7. Sweden: Swedish University of Agricultural Sciences (SLU) and Lund University (2013).

36. Lunner Kolstrup C, Pinzke S. Förebyggande av belastningsbesvär vid arbete $i$ mjölkproduktion - råd och exempel på lösningar. SLU LTJ-report 2013:19. Alnarp: Department of Work Science, Business Economics, and Environmental Psychology (2013). p. 1654-5427.

37. Hermans V, Motmans R, O'Neill D, Roman D, Lundqvist P, Pinzke S, et al. Milking Cows. Good practices in Agriculture: Social Partners Participation in the Prevention of Musculoskeletal Disorders. Leuven: IDEWE, External Prevention Service for Safety and Health at Work (2009).
38. Jakob M, Liebers F, Behrendt S. The effects of working height and manipulated weights on subjective strain, body posture and muscular activity of milking parlor operatives: laboratory study. Appl Ergon (2012) 43:753-61. doi:10.1016/j.apergo.2011.11.009

39. Stål M, Pinzke S. Arbetsmiljö i kostallar Del 2. Belastningsbesvär hos mjölkare i lösdriftsstallar [Musculoskeletal problems in Swedish milking parlour operators]. Report 80. Lund: Institutionen för lantbrukets byggnadsteknik, SLU (1991).

Conflict of Interest Statement: The author declares that the research was conducted in the absence of any commercial or financial relationships that could be construed as a potential conflict of interest.

Copyright $(2016$ Pinzke. This is an open-access article distributed under the terms of the Creative Commons Attribution License (CC BY). The use, distribution or reproduction in other forums is permitted, provided the original author(s) or licensor are credited and that the original publication in this journal is cited, in accordance with accepted academic practice. No use, distribution or reproduction is permitted which does not comply with these terms. 